Article

\title{
Photovoltaic Roof Tiles: The Influence of Heat Recovery on Overall Performance
}

\author{
Jan Wajs *(1), Aleksandra Golabek $(\mathbb{D}$ and Roksana Bochniak $(\mathbb{D}$ \\ Faculty of Mechanical Engineering, Department of Energy and Industrial Apparatus, Gdansk University of \\ Technology, Narutowicza 11/12, 80-233 Gdansk, Poland; aleksandra.golabek@pg.edu.pl (A.G.); \\ roksana.bochniak@pg.edu.pl (R.B.) \\ * Correspondence: jan.wajs@pg.edu.pl; Tel.: +48-583-472-830
}

Received: 18 July 2019; Accepted: 24 October 2019; Published: 27 October 2019

\begin{abstract}
A photovoltaic (PV) roof tile serves both as a roofing material and as an electricity-producing surface. The main aim of the present study was to increase the overall system efficiency of PV tiles by using heat recovery. The chosen strategy was two-fold: determine the operational efficiency of PV tiles and optimize construction to increase the cooling effect when using air as the working medium. A detailed experimental study was undertaken to determine these effects. The results indicated that a combined electrical and thermal efficiency of $24 \%$ could be reached. This is promising and proves the potential for air to be the working medium in such systems. Moreover, this shows a direction for future system optimization.
\end{abstract}

Keywords: photovoltaic (PV) roof tiles; heat recovery; efficiency performance of electricity generation; experimental study; solar light simulator

\section{Introduction}

Climate change related to the development of industry and human activities has reached a stage where it has become necessary to take measures to reduce the harmful effects of impacts on the environment. One of the biggest problems is the phenomenon of global warming, which is caused by the excessive emission of greenhouse gases into the atmosphere. Limiting this is an international matter, which was confirmed by the United Nations Framework Convention on Climate Change (UNFCCC), which connects 196 countries and additionally the European Union [1]. One of the objectives of the European Union's energy and climate policy, which is associated with a reduction of greenhouse gas emissions into the atmosphere, is to increase the share of energy from renewable sources by 2020 to $20 \%$ (of total energy consumption) [2]. According to these assumptions, this share will amount to $24 \%$ by 2030 [2]. The abovementioned requirement is the basis for seeking the most effective solutions for the usage of renewable energy and the reduction of $\mathrm{CO}_{2}$ emissions, depending on the availability of a given source in a specific region.

One example is a study conducted by Italian scientists (Campisi et al. [3]). They compared various solutions for a selected building located in the region of southern Italy. They considered a system that allows for the production of energy that is used for heating/cooling the interior and for hot water for domestic applications. They used a multicriteria analysis that took into account various factors, including energy efficiency, reductions in $\mathrm{CO}_{2}$ emissions, and the availability of raw materials. The obtained results showed that the most advantageous solution was a combination of two renewable energy sources (the usage of solar collectors and a heat pump). This would lead to a reduction in $\mathrm{CO}_{2}$ emissions, almost complete energy self-sufficiency, and the minimization of dependence on traditional energy sources. 
In the renewable energy sector, solar energy systems are experiencing significant developments, with improved solutions that convert energy into electricity or heat. It is worth mentioning that such systems have become even more attractive, taking into account local regulations. Recently, due to the smog danger in some cities (e.g., Krakow in Poland), the burning of coal and wood has become prohibited. Gas furnaces or electric heating are starting to replace traditional heating systems. Therefore, there is an additional space for research regarding mentioned and proposed solar systems, especially their efficiency.

The conversion of solar radiation energy into electricity takes place in a typical photovoltaic (PV) module with a relatively small efficiency range (6-20\%), depending on the solar cell type and climatic conditions [4]. One of the factors determining the efficiency of a PV cell is the temperature of its operation. Experimental research has shown that as solar irradiance increases, the PV cell working temperature also increases, which results in a decrease in its performance. For solar cells made of monocrystalline or polycrystalline silicon, this decrease is about $0.45 \%$ for each degree $(1 \mathrm{~K})$ of temperature increase [5]. Therefore, it has become necessary to develop methods that allow for the minimization of their heating and the application of various ways for their cooling. The desire for this problem solving has contributed to the development of PV/thermal hybrid solar technology $(\mathrm{PV} / \mathrm{T})$. This is a combination of classical PV panels and elements receiving heat from heating panels (e.g., the application of a coil and a liquid or air collector) (used, for example, for heating purposes). The main goal of numerous investigations conducted in this field has been to demonstrate the positive effect of PV panel cooling on the efficiency of electricity generation in comparison to efficiency achieved without cooling.

Teo et al. [6] presented research results from an air-based PV/T system they designed and conducted, in which air was forced to flow through a finned channel under the PV panel. Thanks to the active cooling method, the PV panel could achieve an electrical efficiency at the level of $12-14 \%$, while the electrical performance, at a high panel temperature, was only $8-9 \%$. Cooling allowed for a lowering of the panel's working temperature from $68{ }^{\circ} \mathrm{C}$ to $38^{\circ} \mathrm{C}$. Scientists from Thailand have also demonstrated an increase in power [7]. They lowered the PV panel operating temperature from $46.8^{\circ} \mathrm{C}$ to $27-35^{\circ} \mathrm{C}$ thanks to air-cooling the back wall using a fan. Shahsavar et al. [8] proposed a method for cooling the PV panel with air removed from the building ventilation system, which resulted in an increase in electricity production by approximately $10.1 \%$. In turn, Kim et al. [9] examined the performance parameters of an air-based PV/T collector, obtaining efficiency in converting solar radiation energy into electricity at a level of $15 \%$ and with a thermal efficiency equal to $22 \%$. Heated air removed from the panel casing can be used, according to them, in the ventilation systems of rooms and buildings. Amelia et al. [10] investigated the influence of the number of fans cooling the back wall of a PV panel on improvements in its performance. Hegazy [11] compared four methods of PV panel-cooling using air. He also showed that cooling by blowing air simultaneously above the panel and under it allows for the highest efficiency among the presented methods.

Another research trend in the field of PV/T technology is devoted to the use of water for cooling PV panels. Rahman et al. [12] demonstrated the effectiveness of this cooling using the example of a PV panel made of monocrystalline silicon solar cells. The efficiency of the tested panel increased from $4.5 \%$ to $5.73 \%$, while the temperature on its surface decreased from $88.1{ }^{\circ} \mathrm{C}$ to $65.75^{\circ} \mathrm{C}$. Sayran et al. [13] investigated the change in the PV panel electrical efficiency depending on the depth of its immersion in water, which acted as a heat-receiving factor. Hachicha et al. [14] proved in their experimental studies that water-cooling a PV panel had a positive effect on its efficiency, regardless of whether the front or back wall was cooled or whether both methods were combined. However, they obtained the highest performance by cooling only the front wall of the panel. Research conducted by Indian scientists (Nair et al. [15]) also proved that water-cooling a PV panel front wall allowed for more than $19 \%$ more power than a panel without heat removal, and this decreased the operating temperature from about 65 to about $35^{\circ} \mathrm{C}$. Pradhan et al. [16] increased the efficiency of converting solar radiation energy into electricity by $2 \%$ and decreased a panel's working temperature from $52{ }^{\circ} \mathrm{C}$ to $47^{\circ} \mathrm{C}$ using the same 
method. Similar results were obtained by scientists from Iran (Hosseini et al. [17]). This method was also used by Moharram et al. [18] to keep the PV panel working temperature constant. Bahaidarah et al. [19] raised the PV panel maximum power point (MPP) efficiency from about $15 \%$ to $18 \%$ and decreased its surface temperature from 45 to $35^{\circ} \mathrm{C}$ by water-cooling its back wall.

In the literatures, a comparison of various methods for cooling PV panels has also been made [20-22]. Heat removal in these cases has been carried out, among other methods, using heat sinks, heat pipes, phase change materials (PCMs), air cooling, jet impingement cooling, or water spraying on the panel walls. The presented methods have lowered the temperature of PV panels, thus contributing to improvements in efficiency. However, cooling using the spraying of water has obtained the most significant reduction of a panel's operating temperature (from $66.9^{\circ} \mathrm{C}$ to $37.1^{\circ} \mathrm{C}$ ) and the best parameters of operation. Arshad et al. [23] proved in their research that the active water-cooling of PV panels additionally fitted with lenses concentrating the sun's rays achieved 52\% more power than no heat removal. Prudhvi and Chaitanya [24] used a method of water-cooling the PV panel front wall (in some part of the system flowing underground): this lowered the temperature and allowed for an increase in the efficiency of the panel by 7.75\%. In turn, Wu and Xiong [25] designed and simulated a passive cooling system for the front wall of a PV panel placed on a roof. The cooling medium was water pushed out of the tank using expanding gas, which was in a tank connected to a water tank. This method allowed for a decrease in the panel wall temperature by a maximum of $19{ }^{\circ} \mathrm{C}$ (from $54{ }^{\circ} \mathrm{C}$ to $35^{\circ} \mathrm{C}$ ), thus increasing efficiency by $8.3 \%$.

These achievements, which led to an improvement in the efficiency of solar energy conversion into electricity, are significant due to the possibility of their usage in roofing designs using PV roof tiles. Such systems are novel and developing technologies; therefore, limited knowledge regarding their operation is available.

The research described in this manuscript focused on obtaining the most considerable amount of energy from a "PV roof" for the partial/total coverage of a facility's demand. It concentrated on an improvement in the efficiency of PV cells using cooling methods used in PV/T or building integrated photovoltaics-thermal (BIPV-T) technologies. The concept of this method adaptation to PV roof tile cooling was the basis for the design of an experimental stand. Moreover, the idea of heat recovery was introduced to increase overall system efficiency. The present study was oriented toward the operational characteristics of PV roof tiles, and the results of experimental investigations involving a commercially available PV roof tile are shown. Tests were carried out on a laboratory scale stand using air cooling and a solar light simulator, and because of this it was possible to obtain reproducible values of solar irradiance. Air was selected as the working medium because the PV roof tiles were placed at a given elevation and had direct contact with the surrounding air. Its utilization as a coolant seemed to be reasonable from an economic point of view and also due to limited water resources (for example, in countries with a hot climate). This research focused on an analysis of heat recovery from the PV roof tiles (a determination of heat flux values) and the impact of this process on electrical efficiency and power generation. The overall performance of combination PV roof tiles and air cooling was also determined. It is worth emphasizing that so far, such analyses have not been carried out. Therefore, the added value of this study is related to the concept, the experimental stand design, and the verification of the hypothesis regarding the potential for such solutions.

The main part of the paper consists of Section 2, which includes descriptions of the examined PV roof tile, the solar light simulator, and the experimental setup. Section 3 presents the experimental results together with a discussion. Section 4 describes potential improvements for future research, and Section 5 concludes the presented study. 


\section{The Experimental Approach}

\subsection{The Photovoltaic Roof Tile}

The subject of the research was a commercial PV roof tile, which consisted of nine monocrystalline silicon solar cells. Table 1 shows the basic data concerning its construction, while Table 2 shows the electrical data of the tested unit.

Table 1. Data of the photovoltaic (PV) roof tile construction [26].

\begin{tabular}{ccc}
\hline Quantity & Value & Unit \\
\hline Cell material & Monocrystalline silicon & - \\
Dimensions of the cell & $156 \times 156$ & $\mathrm{~mm}$ \\
Module dimensions & $540 \times 540$ & $\mathrm{~mm}$ \\
Module weight & 3.3 & $\mathrm{~kg}$ \\
Glass thickness & 3.2 & $\mathrm{~mm}$ \\
Mechanical resistance & 5400 & $\mathrm{~Pa}$ \\
Operating temperature & -40 to +80 & ${ }^{\circ} \mathrm{C}$ \\
\hline
\end{tabular}

Table 2. Electrical parameters of the photovoltaic roof tile [26].

\begin{tabular}{ccc}
\hline Parameter & Value & Unit \\
\hline Nominal power & 35 & $\mathrm{~W}$ \\
Tolerance in Standard Test Conditions (STC) & \pm 3 & $\%$ \\
The maximum system voltage (Direct Current, DC) & 1000 & $\mathrm{~V}$ \\
Operating voltage & 4.5 & $\mathrm{~V}$ \\
Operating current & 7.8 & $\mathrm{~A}$ \\
Unloaded voltage & 4.9 & $\mathrm{~V}$ \\
Short-circuit current & 8.2 & $\mathrm{~A}$ \\
Open-Circuit Voltage (UOC) temperature coefficient & $-0.35 \pm 0.02$ & $\% / \mathrm{K}$ \\
Short-Circuit Current (ISC) temperature coefficient & $+0.04 \pm 0.0015$ & $\% / \mathrm{K}$ \\
Maximum Power Point (MPP) temperature coefficient & $-0.5 \pm 0.05$ & $\% / \mathrm{K}$ \\
\hline
\end{tabular}

Cooling of the PV roof tile, which was heated by the influence of incident light, was made possible by placing it in a specially designed wooden casing. It was decided to use wood to reproduce the conditions prevailing on a roof (PV roof tiles, similarly to traditional ones, are attached to a wooden frame). This casing, together with the inlet and outlet, formed a channel through which the air flowed, cooling the back wall of the PV roof tile. To intensify the heat transfer and to direct the air flow, there were special fins mounted on the bottom. The PV roof tile was pressed from the top, preventing its shifting relative to the entire casing. Figure 1 presents a 3D model of the designed casing together with the PV roof tile: this construction only reproduces a small part of the roofing.

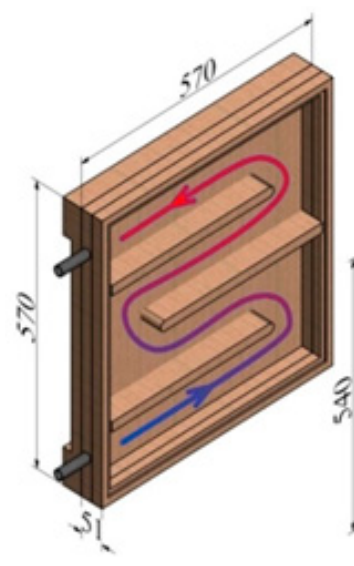

(a)

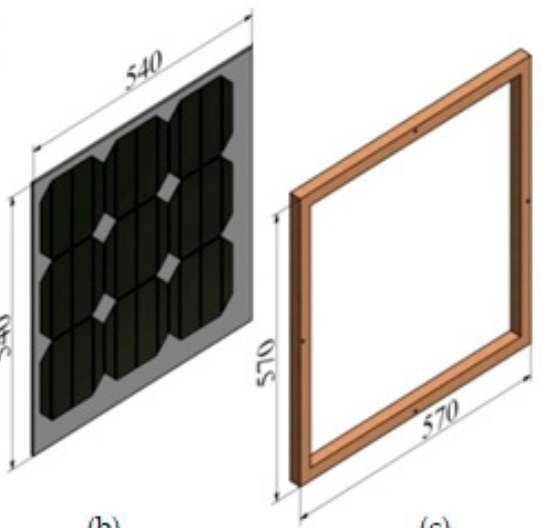

(b) (c)

Figure 1. 3D model of the PV roof tile casing: (a) the wooden casing; (b) the PV roof tile; and (c) the wooden frame. 
As presented above, the PV roof tile, in accordance with the producer's data, could be mounted on a roof in the way shown in Figure 2. The PV roof tiles were hung on metal hooks attached to the roof battens, and a steel cable reinforced the fixing.

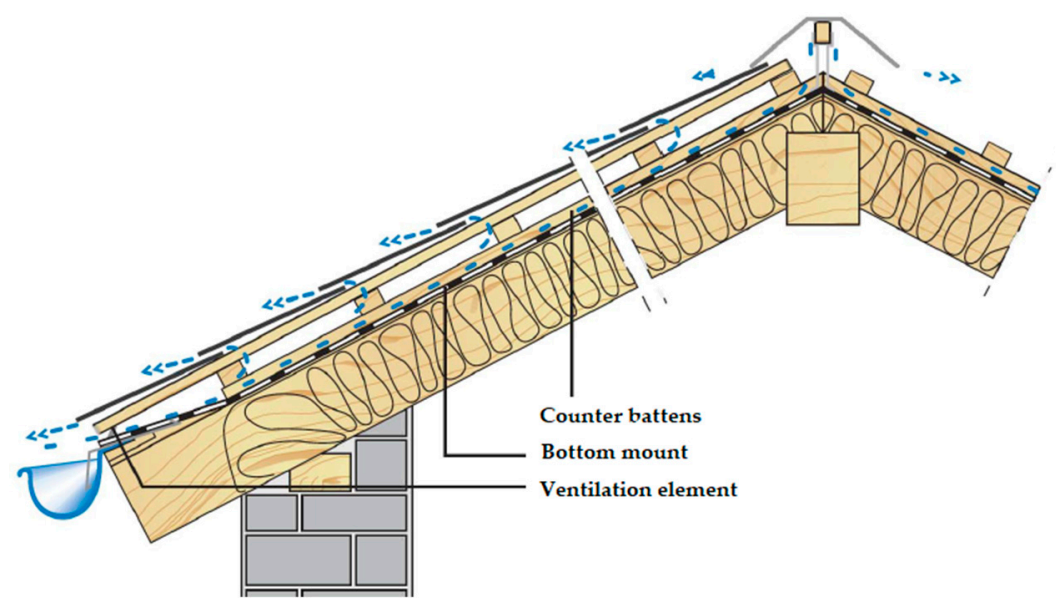

Figure 2. A scheme of mounting the PV roof tile on a roof [26].

\subsection{The Solar Light Simulator}

Since the research was carried out in the laboratory, without access to natural solar radiation, it was necessary to use a halogen light simulator (Figure 3), which imitated the conditions prevailing in the natural environment at an acceptable level [27]. For this purpose, lamps with a total power of $10 \mathrm{~kW}$ were used. A supporting structure of the simulator (the spherical shape with a large radius) ensured that the rays focused on the examined PV roof tile surface. In addition, the use of many radiation sources (in this case, 20 lamps) was more advantageous than the case with a single source [27]. Additionally, by adjusting the lamps supply voltage, it was possible to control the light beam of the radiation source precisely: this allowed for performing tests in a wide range of solar irradiance. The PV roof tile was $1.5 \mathrm{~m}$ away from the presented solar light simulator, which was in a configuration reflecting the position of the sun at the zenith: the light rays were the shortest, and the air mass coefficient (AM) was $A M=1$.

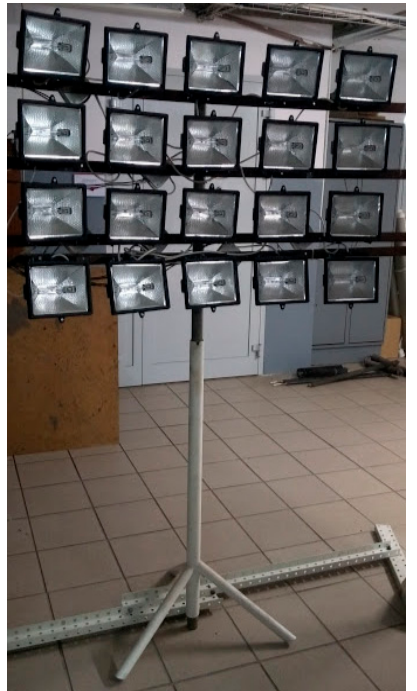

(a)

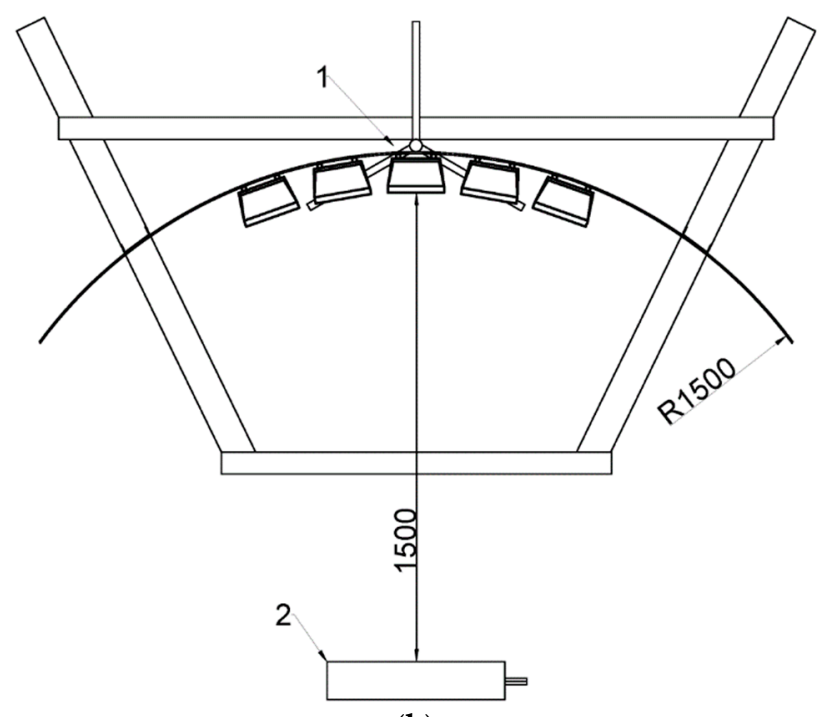

(b)

Figure 3. The solar light simulator: (a) photography of the solar light simulator; and (b) a scheme of the simulator's location relative to the PV roof tile casing. 1: The solar light simulator; and 2: the PV roof tile casing. 


\subsection{The Experimental Setup}

The dedicated experimental setup was located in the Department of Energy and Industrial Apparatus of the Gdansk University of Technology (Gdańsk, Poland). It consisted of the above-described PV roof tile together with the casing, which formed a flow channel of cooling air with a height of $51 \mathrm{~mm}$. This set was placed on a tripod perpendicular to the ground. Figure 4 shows a view of the PV roof tile with the casing and the solarimeter.

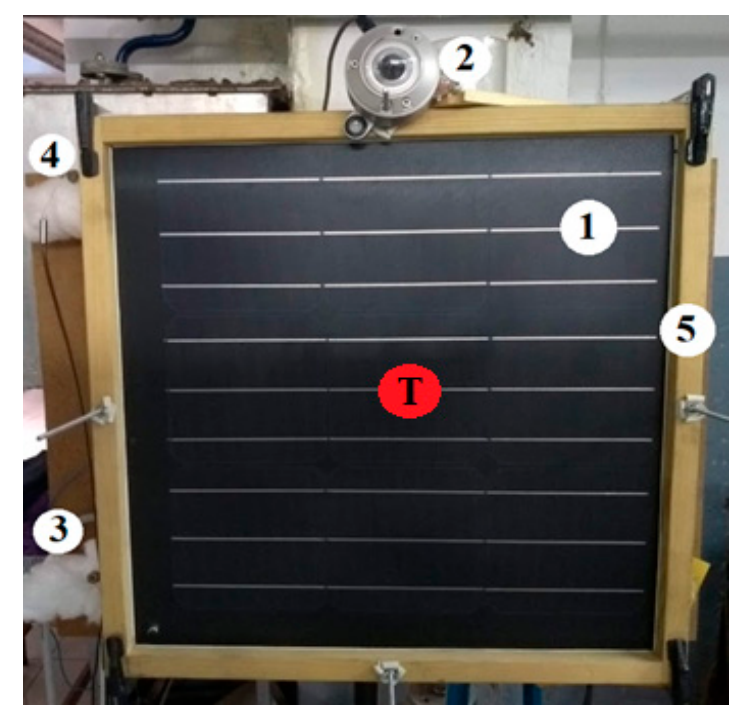

Figure 4. The PV roof tile with the casing and the solarimeter. 1: The PV roof tile; 2: the solarimeter; 3 : the air inlet; 4 : the air outlet; 5 : the wooden frame; $\mathbf{T}$ : the location of the temperature measurement.

One of the connectors located in the casing was connected to the cooling medium transporting duct. The air was forced to flow using a radial fan to reproduce natural conditions, cooling the PV roof tiles through air flow at a speed of about $3 \mathrm{~m} / \mathrm{s}$ (this was the air speed at the cooling medium duct inlet) on a sunny day. The usage of a device (for example, a radial fan) that can force air flow and increase heat transfer is vital in the countries with a hot climate, where the ambient air temperature is high and the possibility of heat removal from the heated elements is limited. Launay et al. [28] observed that wind speed is one of the key factors that is responsible for an increase in the power output in high ambient temperatures. A higher value of the wind speed ensures better cooling of the PV panels. The solar irradiance was measured by a solarimeter, which was located on the front frame of the designed casing (see Figure 4). The output signal was the voltage, which was converted to solar irradiance using a solarimeter sensitivity index: according to the manufacturer's data, this was equal to $11.44 \times 10^{-6} \mathrm{~V} /\left(\mathrm{W} / \mathrm{m}^{2}\right)$. It was assumed that the distribution of the solar irradiance on the PV roof tile was uniform: the values changed negligibly depending on the position of the solarimeter. These features were verified in the test experiments. They showed that the solar irradiance measured at nine representative points (the center of each cell) was close to $\pm 2 \%$ of the solar irradiance average value on the tested PV roof tile. A pyrometer measured the PV roof tile surface temperature at the location marked in Figure 4. This place was selected because its temperature was close to the average temperature on the PV roof tile surface, calculated for nine representative points (in the center of each solar cell). The air temperature at the inlet and outlet was determined using T-type thermocouples and a signal transducer. The electrical parameters of the PV roof tile (voltage and electrical current) were measured using a slider resistor and two multimeters. Table 3 lists the applied sensors, detectors, and meters together with their measurement accuracy. 
Table 3. Measuring equipment.

\begin{tabular}{|c|c|c|c|}
\hline Measured Parameter & Device Name & Measurement Error & Unit \\
\hline $\begin{array}{l}\text { Inlet and outlet temperature of } \\
\text { the cooling air }\end{array}$ & $\begin{array}{c}\text { Cropico-3001 TC/Pt } 100 \\
\text { (Seaward Electronic Ltd, Peterlee, UK) }\end{array}$ & \pm 0.01 & ${ }^{\circ} \mathrm{C}$ \\
\hline $\begin{array}{l}\text { The voltage generated by the PV } \\
\text { roof tile }\end{array}$ & $\begin{array}{c}\text { DT-830B } \\
\text { (MASTECH Group, Guangdong, China) }\end{array}$ & \pm 0.1 & $\mathrm{~V}$ \\
\hline PV roof tile electrical current & $\begin{array}{c}\text { DT-830BUZ } \\
\text { (Uni-Trend Technology, Dongguan, China) }\end{array}$ & \pm 0.2 & A \\
\hline Air flow rate & $\begin{array}{c}\text { Rol-164 } \\
\text { (Zakłady Automatyki Rotametr Sp. z o.o., } \\
\text { Gliwice, Poland) }\end{array}$ & \pm 0.1 & $\mathrm{~m}^{3} / \mathrm{h}$ \\
\hline $\begin{array}{l}\text { Temperature of PV roof tile } \\
\text { surface }\end{array}$ & $\begin{array}{c}\text { Fluke } 62 \mathrm{mini} \\
\text { (Fluke Europe, Eindhoven, The Netherlands) }\end{array}$ & \pm 1.5 & ${ }^{\circ} \mathrm{C}$ \\
\hline Solar irradiance & $\begin{array}{c}\text { Kipp \& Zonen CM6B } \\
\text { (Kipp \& Zonen B.V., Delft, The Netherlands) }\end{array}$ & \pm 40 & $\mathrm{~W} / \mathrm{m}^{2}$ \\
\hline
\end{tabular}

\section{Experimental Results}

The experimental research was divided into two stages: analysis of the PV roof tile without and with cooling. At first, the electrical parameters of the PV roof tile without cooling were measured. This was the basis for a current voltage and electrical power voltage characteristics determination and the basis for the photoelectric efficiency of the solar radiation conversion (depending on the solar irradiance calculations). The experiment also recorded the effect of solar irradiance on the temperature change on the PV roof tile surface.

The generated electrical power at the MPP was calculated from the following formula:

$$
M P P=U \cdot I
$$

where $U$ is the operating voltage at the MPP and $I$ is the operating electrical current at the MPP.

The electrical efficiency of the PV roof tile $\left(\eta_{e}\right)$ was calculated based on the equation:

$$
\eta_{e}=\frac{M P P}{G \cdot S} \cdot 100 \%
$$

where $G$ is the solar irradiance and $S$ is the active surface of the PV roof tile, which is equal to $0.22 \mathrm{~m}^{2}$.

In the next stage of study, measurement series for the cooled back wall of the PV roof tile were carried out. The gathered characteristics allowed for determining the effect of cooling on the essential parameters of the operation. In addition, the heat flux $(q)$, which can be obtained for a given solar irradiance, was calculated from the equation:

$$
q=\frac{\rho \cdot \dot{V} \cdot c \cdot \Delta T}{M}
$$

where $\rho$ is the average air density between the inlet and outlet temperature, $\dot{V}$ is the volumetric flow rate of air, $c$ is the average air-specific heat between the inlet and outlet temperature, $\Delta T$ is the outlet and inlet air temperature difference, and $M$ is the total surface of the PV roof tile module (which is equal to $0.29 \mathrm{~m}^{2}$ ).

The photothermal conversion efficiency $\left(\eta_{t h}\right)$ was determined based on the equation:

$$
\eta_{\text {th }}=\frac{\rho \cdot \dot{V} \cdot c \cdot \Delta T}{M \cdot G} \cdot 100 \%
$$


The overall efficiency $\left(\eta_{0}\right)$ of the PV roof tile was calculated as the sum of the electrical and thermal efficiencies:

$$
\eta_{o}=\eta_{e}+\eta_{t h}
$$

Figure 5 presents the current voltage and electrical power voltage characteristics obtained for the PV roof tile without cooling depending on the solar irradiance. These characteristics show that with an increase in solar irradiance, the generated electrical power also increased; however, the highest obtained value (for a solar irradiance of $900 \mathrm{~W} / \mathrm{m}^{2}$ ) was relatively small $(9.39 \mathrm{~W}$ ).

The characteristics plotted in Figure 6 show changes in the temperature of the PV roof tile front wall as a function of the solar irradiance. The temperature of the noncooled PV roof tile surface for a solar irradiance equal to $900 \mathrm{~W} / \mathrm{m}^{2}$ was about $80^{\circ} \mathrm{C}$, i.e., the maximum working temperature given by the manufacturer [23]. Due to the risk of halogen lamps damage from long operation and the overheating of cells at high solar irradiance, the tests were carried out for a solar irradiance of up to $900 \mathrm{~W} / \mathrm{m}^{2}$. Cooling with the volumetric flow rate of air equal to $5 \mathrm{~m}^{3} / \mathrm{h}$ caused a decrease in the temperature at the roof tile surface of approximately $8{ }^{\circ} \mathrm{C}$ (the maximum) at a solar irradiance equal to $750 \mathrm{~W} / \mathrm{m}^{2}$. During the tests, it was impossible to lower the PV roof tile temperature below $50{ }^{\circ} \mathrm{C}$.

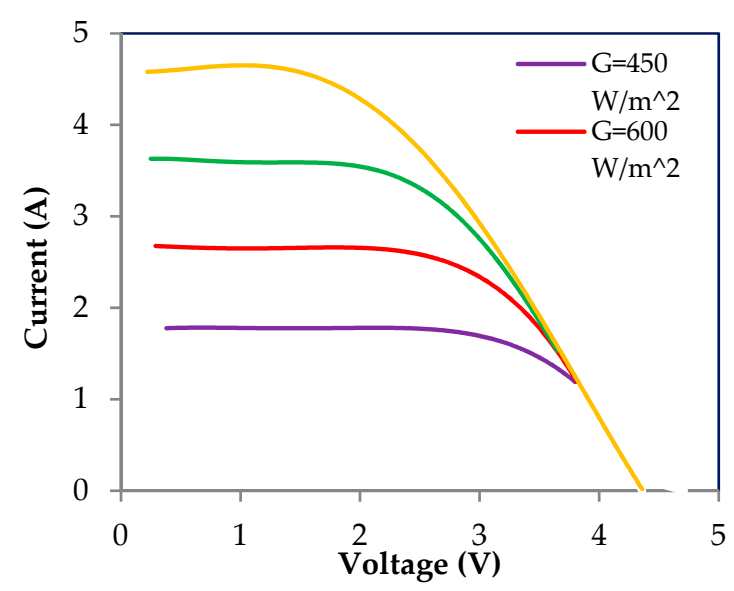

(a)

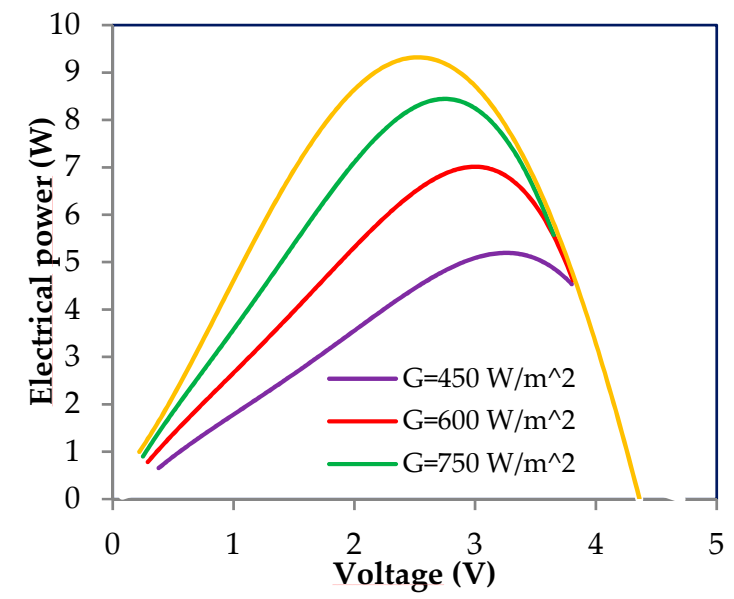

(b)

Figure 5. Characteristics of the noncooled PV roof tile: (a) current voltage; and (b) electrical power voltage.

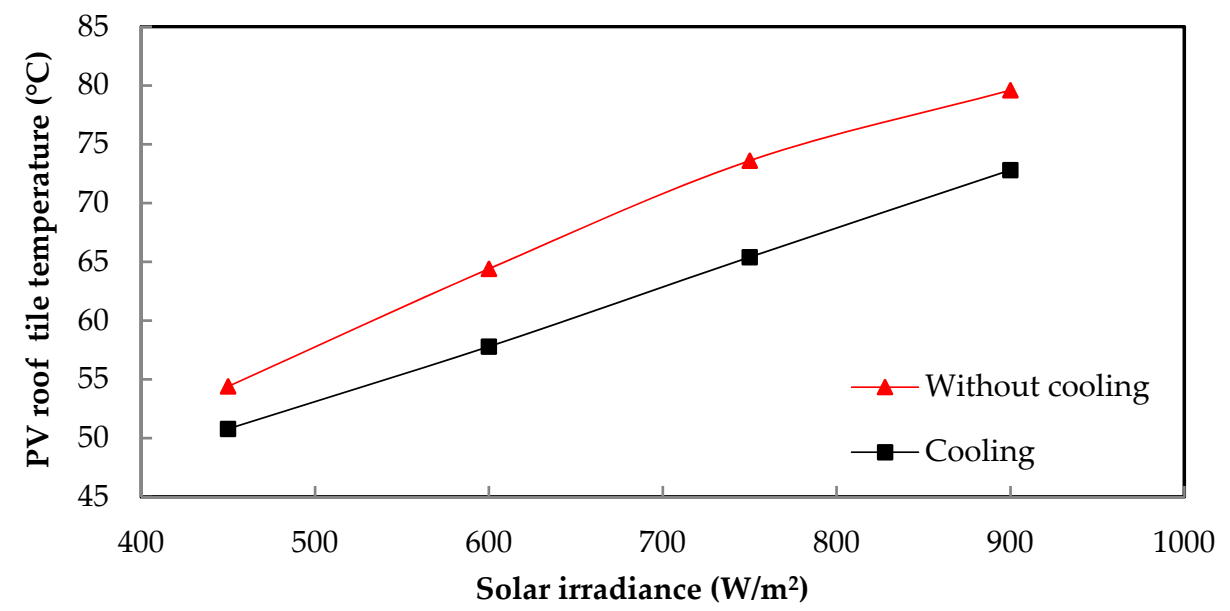

Figure 6. The PV roof tile temperature variation with the solar irradiance, with the cooling air flow rate at $\dot{V}=5 \mathrm{~m}^{3} / \mathrm{h}$. 
Figure 7a shows characteristics of the PV roof tile electrical power as a function of the solar irradiance. At a solar irradiance equal to $900 \mathrm{~W} / \mathrm{m}^{2}$, the electric power generated by the cooled PV roof tile was higher by about $9 \%$ than the power obtained in the absence of cooling. For each value of the solar irradiance, cooling of the back wall of the PV roof tile allowed for an increase in the generated electrical power.

The electrical efficiency characteristics of the PV roof tile plotted as a function of the solar irradiance are also shown in Figure $7 \mathrm{~b}$. Heat removal from the back wall of the PV roof tile caused an increase in electrical efficiency by $9.5 \%$ (maximum) in relation to operation without cooling. Additionally, the highest values of electrical efficiency for the two cases (without and with cooling) were obtained for a solar irradiance equal to $600 \mathrm{~W} / \mathrm{m}^{2}$ : after this, they started to decrease with a rise in solar irradiance. This could have been caused by the high operating temperature of the PV roof tile for solar irradiance above $600 \mathrm{~W} / \mathrm{m}^{2}$. Similarly to the generated electrical power, air cooling also allowed for an increase in electrical efficiency for each assumed value of solar irradiance.

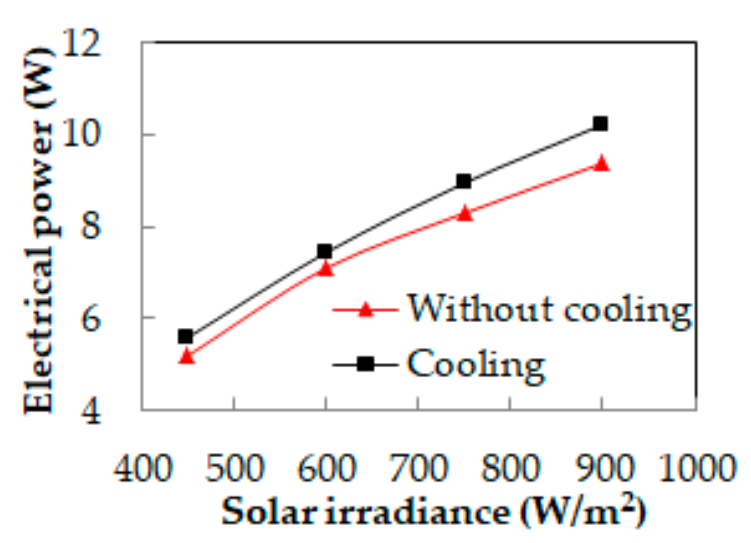

(a)

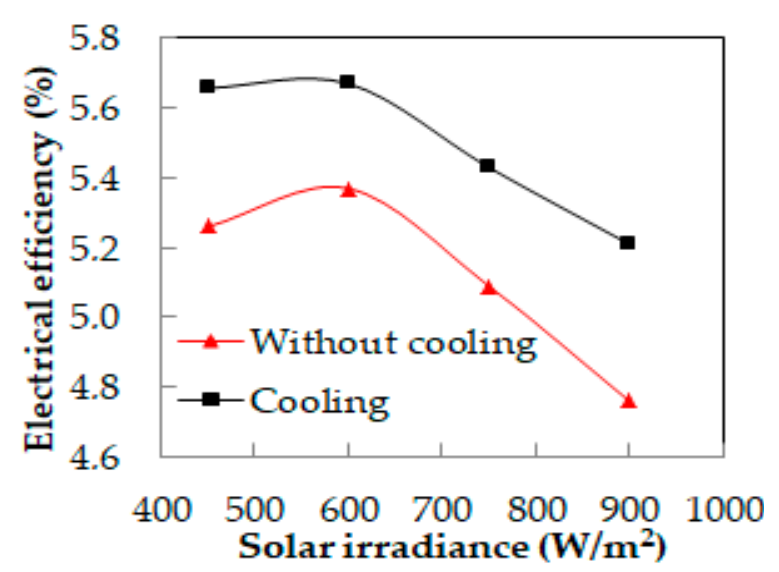

(b)

Figure 7. The PV roof tile electrical characteristics: (a) the electrical power variation with the solar irradiance; and (b) the electrical efficiency variation with the solar irradiance.

Table 4 presents the results of thermal tests of the PV roof tile carried out at a given volumetric air flow rate (equal to $5 \mathrm{~m}^{3} / \mathrm{h}$ ). As the solar irradiance increased, the amount of removed heat from the PV roof tile also increased. During the tests, it was noted that at a solar irradiance of $900 \mathrm{~W} / \mathrm{m}^{2}$, the obtained heat flux was about $164 \mathrm{~W} / \mathrm{m}^{2}$. The increase in the air temperature at this condition was approximately $30 \mathrm{~K}$.

Table 4. Comparison of temperature and heat flux values, with the cooling air flow rate at $\dot{V}=5 \mathrm{~m}^{3} / \mathrm{h}$.

\begin{tabular}{ccccc}
\hline $\begin{array}{c}\text { Solar Irradiance } \\
\left(\mathbf{W} / \mathbf{m}^{\mathbf{2}}\right)\end{array}$ & $\begin{array}{c}\text { Inlet Temperature } \\
\left.\mathbf{(}{ }^{\circ} \mathbf{C}\right)\end{array}$ & $\begin{array}{c}\text { Outlet Temperature } \\
\left.\mathbf{(}{ }^{\circ} \mathbf{C}\right)\end{array}$ & $\begin{array}{c}\text { Temperature Difference } \\
\left({ }^{\circ} \mathbf{C}\right)\end{array}$ & $\begin{array}{c}\text { Heat Flux } \\
\left(\mathbf{W} / \mathbf{m}^{\mathbf{2}}\right)\end{array}$ \\
\hline 450 & 27.6 & 39.8 & 12.2 & 68.75 \\
600 & 29.5 & 48.2 & 18.7 & 103.66 \\
750 & 30.9 & 55.4 & 24.5 & 133.99 \\
900 & 32.2 & 62.6 & 30.4 & 164.08 \\
\hline
\end{tabular}

Figure 8 shows the efficiency characteristics (electrical, thermal, and overall) of the cooled PV roof tile. At the given volumetric air flow rate $\left(5 \mathrm{~m}^{3} / \mathrm{h}\right)$, the maximum overall efficiency of the tested PV roof tile was $23.5 \%$ at a solar irradiance of $900 \mathrm{~W} / \mathrm{m}^{2}$. This was an effect of obtaining electrical efficiency at the level of $5.2 \%$ (and a thermal efficiency equal to $18.3 \%$ ) under this condition. 


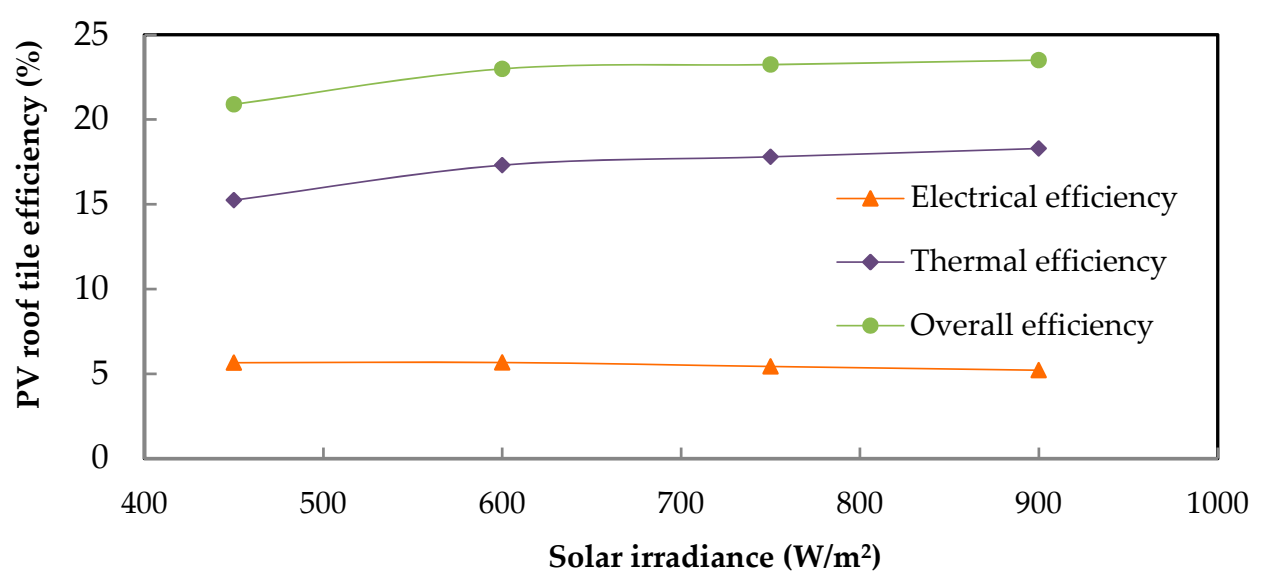

Figure 8. Cooled PV roof tile efficiency variation with the solar irradiance $\left(\dot{V}=5 \mathrm{~m}^{3} / \mathrm{h}\right)$.

\section{Possible Improvements in Research}

Since the presented research is only the first step in PV roof tile examination, improvements are planned in the near future.

The most crucial issue is to ensure Standard Test Conditions (STC) during the experiment: this would allow for comparing the producer's data to the obtained results. In this paper, only the results obtained during the experimental tests were compared to each other, which produced a focus on the overall positive effect of $\mathrm{PV}$ roof tile cooling on the operational parameters. Improving the experimental setup by providing the right air mass coefficient value and using an accredited device will be the next stage of research, because the authors are aware that these factors have a significant impact on the obtained results. It is essential to continue the experimental research using various types of turbulators placed in the air flow duct and different configurations to ensure the intensification of heat removal from the PV roof tile. Before this, numerical simulations should be performed to obtain the best geometrical arrangement, which then will be tested using a laboratory stand. These simulations will allow for energy balance in the entire system, and they are not presented here because they were not the focus at the time. Since the system was not optimized, the energy balance would have been misleading, and it is worth making additional efforts toward better operation of the system before its calculation. Additionally, the long-term aim is a numerical analysis oriented toward the optimization of the generated (by the radial fan) volumetric flow rate and its further experimental validation.

Moreover, the system discussed in this paper considered only one PV roof tile; therefore, the natural extension of the experimental study is to investigate the matrix of several PV roof tiles and assess heat removal from a larger working surface. The extended system will be analyzed in terms of a standard PV roof tile and an optimized one with turbulators in the air flow duct. However, this will require the usage of a larger solar radiation simulator or the implementation of the experimental research in natural conditions.

\section{Conclusions}

The operational characteristics of analyzed cooled PV roof tiles revealed an increase in generated electrical power, which was related to a rise in the efficiency of solar energy conversion into electricity. The experimental results also showed that air cooling was sufficient enough to observe this effect. Moreover, heat recovery from the cooling system contributed to an increase in the overall efficiency of the system. Since so far such analyses have not been carried out, it was hard to design the experimental system. However, the assumptions made during the design of the experimental stand were verified, and this opens the way for further analyses.

The efficiency of the single PV roof tile and the maximum power produced by it under laboratory conditions were $5.67 \%$ (for a solar irradiance equal to $600 \mathrm{~W} / \mathrm{m}^{2}$ ) and $10.23 \mathrm{~W}$ (for a solar irradiance of $900 \mathrm{~W} / \mathrm{m}^{2}$ ). These values were lower than the producer's data (nominal power equal to $35 \mathrm{~W}$ in STC 
conditions; see Table 2). The reason for these results could have been because halogen lamps have a shifted radiation spectrum in relation to natural solar radiation or because it was used a value for the air mass coefficient $(A M=1)$ during the experimental research that was different from Standard Test Conditions $(A M=1.5)$. However, it should be emphasized that the obtained electrical efficiency of the PV tile, although it was determined in artificial light, was within the range of values published in the literature, namely from about $3 \%$ to about $15 \%[29,30]$. The efficiency value depended on the system and the conditions under which the experiments were carried out.

The maximum operating temperature of the tested PV roof tile without cooling was $79.6^{\circ} \mathrm{C}$ for a solar irradiance equal to $900 \mathrm{~W} / \mathrm{m}^{2}$, and with cooling, it was equal to $72.2^{\circ} \mathrm{C}$. The cooling of the PV roof tile back wall allowed for about $9 \%$ more power and about $9.5 \%$ more electrical efficiency than in the case without cooling. Due to the cooling of the PV roof tile back wall, a flux equal to $164 \mathrm{~W} / \mathrm{m}^{2}$ of heat was recovered, with a thermal efficiency of $18.3 \%$. An increase in the air temperature of about $30.4 \mathrm{~K}$ at a volumetric flow rate equal to $5 \mathrm{~m}^{3} / \mathrm{h}$ was noticed in this case. The maximum overall efficiency of the cooled PV roof tile was $23.5 \%$.

The obtained results indicate the necessity of PV roof tile cooling during unfavorable working conditions, and show that the heat recovery system can improve efficiency. The heat fluxes obtained during the cooling of the PV roof tile back wall are promising. The heated air can be used as a lower heat source for an air heat pump, a technology often found in low-energy buildings, or it can supply heat storage connected to, e.g., Organic Rankine Cycle (ORC) technology. This solution can also be used as a kind of BIPV-T system: the cooled air can be used for, e.g., air conditioning technology.

Author Contributions: Conceptualization, J.W., A.G. and R.B.; Data curation, A.G. and R.B.; Formal analysis, A.G. and R.B.; Funding acquisition, J.W.; Investigation, A.G. and R.B; Methodology, J.W.; Project administration, J.W., A.G. and R.B.; Resources, J.W.; Supervision, J.W.; Validation, J.W., A.G. and R.B.; Visualization, A.G. and R.B.; Writing - original draft, A.G., R.B. and J.W.; Writing - review \& editing, J.W.

Funding: This research received no external funding.

Conflicts of Interest: The authors declare no conflict of interest.

\section{References}

1. United Nations Climate Change. Available online: https://unfccc.int/ (accessed on 29 August 2019).

2. A Policy Framework for Climate and Energy in the Period from 2020 to 2030. Communication from the Commission to The European Parliament, The Council, The European Economic and Social Committee and the Committee of the Regions. Brussels 22.01.2014. Available online: https://eur-lex.europa.eu/legal-content/ EN/ALL/?uri=CELEX\%3A52014DC0015 (accessed on 29 August 2019).

3. Campisi, D.; Gitto, S.; Morea, D. An Evaluation of Energy and Economic Efficiency in Residential Buildings Sector: A Multi-criteria Analisys on an Italian Case Study. Int. J. Energy Econ. Policy 2018, 8, 185-196.

4. Dubey, S.; Sarvaiya, J.N.; Seshadri, B. Temperature dependent photovoltaic (PV) efficiency and its effect on PV production in the world-A review. Energy Procedia 2013, 33, 311-321. [CrossRef]

5. Kalogirou, S.A.; Tripanagnostopoulos, Y. Hybrid PV/T solar systems for domestic hot water and electricity production. Energy Convers. Manag. 2006, 47, 3368-3382. [CrossRef]

6. Teo, H.G.; Lee, P.S.; Hawlader, M.N.A. An active cooling system for photovoltaic modules. Appl. Energy 2012, 90, 309-315. [CrossRef]

7. Sreewirote, B.; Noppakant, A.; Pothisarn, C. Increasing efficiency of an electricity production system from solar energy with a method of reducing solar panel temperature. In Proceedings of the International Conference on Applied System Innovation (ICASI), Sapporo, Japan, 13-17 May 2017; pp. 1308-1311.

8. Shahsavar, A.; Salmanzadeh, M.; Ameri, M.; Talebizadeh, P. Energy saving in buildings by using the exhaust and ventilation air for cooling of photovoltaic panels. Energy Build. 2011, 43, 2219-2226. [CrossRef]

9. Kim, J.H.; Park, S.H.; Kim, J.T. Experimental performance of a photovoltaic-thermal air collector. Energy Procedia 2014, 48, 888-894. [CrossRef]

10. Amelia, A.R.; Irwan, Y.M.; Irwanto, M.; Leow, W.Z.; Gomesh, N.; Safwati, I.; Anuar, M.A.M. Cooling on photovoltaic panel using forced air convection induced by DC fan. Int. J. Electr. Comput. Eng. 2016, 6, 526-534. [CrossRef] 
11. Hegazy, A. Comparative study of the performances of four photovoltaic/thermal solar air collectors. Energy Convers. Manag. 2000, 41, 861-881. [CrossRef]

12. Rahman, M.M.; Hasanuzzaman, M.; Rahim, N.A. Effects of various parameters on PV-module power and efficiency. Energy Convers. Manag. 2015, 103, 348-358. [CrossRef]

13. Sayran, A.A.; Omar, S.O.; Kamil, M.Y. Improving the efficiency of polycrystalline solar panel via water immersion method. Int. J. Innov. Res. Sci. Eng. Technol. 2014, 3, 8127-8132.

14. Hachicha, A.; Ghenai, C.; Hamid, A.K. Enhancing the performance of a photovoltaic module using different cooling methods. World Acad. Sci. Eng. Technol. Int. J. Energy Power Eng. 2015, 9, 1106-1109.

15. Nair, M.; Midhun, A.; Febin, F.; Jithu, F. Enhancing the efficiency of solar panel using cooling systems. Int. J. Eng. Res. Appl. 2017, 7, 5-7.

16. Pradhan, A.; Parashar, S.K.S.; Ali, S.M.; Paikray, P. Water cooling method to improve efficiency of photovoltaic module. In Proceedings of the International Conference on Signal Processing, Communication, Power and Embedded System (SCOPES), Paralakhemundi, India, 3-5 October 2016; pp. 1044-1047.

17. Hosseini, R.; Hosseini, N.; Khorasanizadeh, H. An experimental study of combining a photovoltaic system with a heating system. In Proceedings of the World Renewable Energy Congress, Linköping, Sweden, 8-13 May 2011; pp. 2993-3000.

18. Moharram, K.A.; Abd-Elhady, M.S.; Kandil, H.A.; El-Sherif, H. Enhancing the performance of photovoltaic panels by water cooling. Ain Shams Eng. J. 2013, 4, 869-877. [CrossRef]

19. Bahaidarah, H.; Subhan, A.; Gandhidasan, P.; Rehman, S. Performance evaluation of a PV (photovoltaic) module by back surface water cooling for hot climatic conditions. Energy 2013, 59, 445-453. [CrossRef]

20. Khan, M.A.; Ko, B.; Nyari, E.A.; Park, S.E.; Kim, H.J. Performance evaluation of photovoltaic solar system with different cooling methods and a bi-reflector PV system (BRPVS): An experimental study and comparative analysis. Energies 2017, 10, 826. [CrossRef]

21. Zubeer, S.A.; Mohammed, H.A.; Ilkan, M. A review of photovoltaic cells cooling techniques. E3S Web of Conferences. Proceedings of International Conference on Advances in Energy Systems and Environmental Engineering (ASEE17), Wrocław, Poland, 2-5 July 2017; Volume 22, p. 00205.

22. Sato, D.; Yamada, N. Review of photovoltaic module cooling methods and performance evaluation of the radiative cooling method. Renew. Sustain. Energy Rev. 2019, 104, 151-166. [CrossRef]

23. Arshad, R.; Tariq, S.; Niaz, M.U.; Jamil, M. Improvement in solar panel efficiency using solar concentration by simple mirrors and by cooling. In Proceedings of the International Conference on Robotics and Emerging Allied Technologies in Engineering (iCREATE), Islamabad, Pakistan, 22-24 April 2014; pp. 292-295.

24. Prudhvi, P.; Chaitanya, S.P. Efficiency improvement of solar PV panels using active cooling. In Proceedings of the 11th International Conference on Environment and Electrical Engineering, Venice, Italy, 18-25 May 2012; pp. 1093-1097.

25. Wu, S.; Xiong, C. Passive cooling technology for photovoltaic panels for domestic houses. Int. J. Low Carbon Technol. 2014, 9, 118-126. [CrossRef]

26. Producer Data, SolteQ Europe GmbH, Catalog SolteQ Solarroofs. Available online: http://www.solteq.eu/ SolteQ-Catalog-Solarroofs.pdf (accessed on 25 October 2019).

27. Ratajczak, J. The Issues of Spectrally-Thermal Simulation of Solar Radiation. Ph.D. Thesis, Poznan University of Technology, Poznan, Poland, 2013.

28. Launay, J.; Lee, E.W.M.; Bennacer, R.; Yuen, R.K.K. Analysis of factors affecting the performance of BIPV panels. Eur. Phys. J. Appl. Phys. 2018, 84, 10902. [CrossRef]

29. Mirzaei, M.; Mohiabadi, M.Z. A comparative analysis of long-term field test of monocrystalline and polycrystalline PV power generation in semi-arid climate conditions. Energy Sustain. Dev. 2017, 38, 93-101. [CrossRef]

30. Reddy, S.R.; Ebadian, M.A.; Lin, C.-X. A review of PV-T systems: Thermal management and efficiency with single phase cooling. Int. J. Heat Mass Transf. 2015, 91, 861-871. [CrossRef]

(C) 2019 by the authors. Licensee MDPI, Basel, Switzerland. This article is an open access article distributed under the terms and conditions of the Creative Commons Attribution (CC BY) license (http://creativecommons.org/licenses/by/4.0/). 